\title{
A PROTOYPE OF DIGITAL BLOOD PRESSURE MEASUREMENT DEVICE BASED ON ARDUINO UNO AND MOBILE APPLICATION
}

\author{
Muhammad Rifqi Ma'arif ${ }^{1}$, Agung Priyanto ${ }^{2}$ \\ ${ }^{1}$ Program Studi Sistem Informasi, ${ }^{2}$ Program Studi Teknologi Informasi \\ Fakultas Tekni dan Teknologi Informasi, Universitas Jenderal Achmad Yani Yogyakarta \\ Jl. Siliwangi Km. 0,7, Banyuraden, Gamping, Sleman, Yogyakarta \\ ${ }^{1}$ rifqi@unjaya.ac.id, ${ }^{2}$ agungpriyanto@unjaya.ac.id
}

\begin{abstract}
Blood pressure is one of the vital sign which widely used as a parameter for medical examination. In some cases likes hypertension, cardiovascular disease or routine examination of pregnant woman, blood pressure test which performed frequently become an important thing. Based on those cases, hence an availability of blood pressure measurement devices will become significant. Thus, in this research, we developed a prototype od digital blood pressure measurement device by using Arduino Uno microcontroller and Android based mobile application. In general, Arduino Uno was equipped with pressure sensor MPX5050DP, those devices will be used for blood pressure measurement. Then the result will be sent and displayed to mobile application. Data transmission between hardware and mobile application was done by using bluetooth module.
\end{abstract}

Keywords : Blood Pressure, Arduino Uno, Mobile Application, Android, Bluetooth

\section{Latar Belakang Masalah}

Di dunia medis, lazim ditemui berbagai macam alat untuk mengukur indikator-indikator vital dari tubuh manusia. Tingkat kesulitan pengukuran pun sangat beragam mulai dari yang sangat mudah seperti suhu tubuh sampai indikator yang cukup sulit untuk diukur seperti sinyal elektrokardiogram (ECG) atau elektrochepalogram (EEG). Salah satu indikator tubuh yang cukup sering diukur dalam pemeriksaan medis untuk berbagai macam keperluan adalah tekanan darah. Tujuan mendasar dari tekanan darah adalah untuk mengetahui kondisi sistem kardiovaskuler yang bertugas untuk mendistribusikan darah ke seluruh bagian tubuh. Tekanan darah yang terlalu tinggi (hipertensi) menunjukkan kerja sistem kardiovaskuler terlalu berat sehingga sangat berbahaya bagi pasien[1]. Sebagai contoh, kelainan dalam tekanan darah (hypertensive disorder) merupakan penyebab utama komplikasi pada kehamilan yang memicu terjadinya kematian pada ibu hamil[2].

Saat ini alat yang cukup popular dan menjadi gold standard untuk pengukuran tekanan darah adalah sebuah alat yang disebut tensimeter/sphygnomagnometer. Tensimeter konvensional yang saat ini masih banyak digunakan memanfaatkan manset yang dialiri udara dan diikatkan pada lengan pasien. Tekanan udara dalam manset kemudian dikonversikan menjadi tekanan udara dan ditunjukkan dalam indikator berskala yang menggunakan air raksa/merkuri yang dapat dibaca oleh tenaga medis. Alat ini cukup sulit untuk digunakan oleh orang awam karena menggunakan alat tambahan berupa stetoskop untuk menentukan sistole dan diastole pasien melalui bunyi detak jantung dengan teknik korotof[3]. Selain itu, pengguna juga harus cukup terampil dalam mengatur udara keluar dari manset agar tekanan udara berkurang secara perlahan.

Seiring dengan perkembangan teknologi, saat ini di pasaran sudah banyak tersedia tensimeter digital yang dapat lebih mudah digunakan oleh orang awam. Meskipun hasil pengukuran oleh tensimeter digital tidak lebih akurat dari alat konvensional, namun tensimeter digital bisa menjadi alternative bagi masyarakat untuk bisa mengukur dan memantau tekanan darahnya secara mandiri. Pada penelitian ini akan dikembangkan tensimeter digital yang selain dapat membantu/memudahkan pasien dalam mengukur tekanan darah secara mandiri, juga dilengkapi dengan aplikasi mobile berbasis Android. Aplikasi mobile tersebut selain menjadi display tambahan untuk hasil pengukuran juga dapat digunakan sebagai perantara penyimpanan data. Sehingga hasil-hasil pengukuran yang sudah dilakukan pada masa-masa sebelumnya bisa disimpan 
dan digunakan untuk berbagai macam keperluan. Alat ukur tekanan darah yang dikembangkan dalam penelitian ini memanfaatkan mikrokontroler Arduino. Salah satu alas an digunakannya Arduino adalah dari sisi fleksibilitas dimana papan mikrokontroller Arduino dapat dengan mudah dikonfigurasikan dengan berbagai macam perangkat sensor dan modul. Sensor yang digunakan dalam penelitian ini adalah sensor tekanan MPX5050 dengan perangkat tambahan berupa modul bluetooth HC05 sebagai antarmuka untuk transmisi data dengan aplikasi mobile.

\section{Landasan Teori}

\subsection{Papan Mikrokontroler Arduino Uno}

Arduino merupakan platform board elektronik open source yang mudah digunakan baik dari sisi perangkat keras maupun perangkat lunak. Board Arduino mampu membaca input dari berbagai macam sensor dan mengeluarkan bermacam output dari hasil pembacaan tersebut[4]. Output bisa berupa menyalakan LED, mengaktifkan aktuator, maupun mengirimkan data ke komputer lain. Pada beberapa tahun terakhir, Arduino menjadi platform board elektronika yang banyak digunakan dalam berbagai macam proyek. Mulai dari proyek komunitas skala kecil[5], sampai dengan proyek sains yang sangat kompleks[6]. Gambar 2.1 berikut menunjukkan bentuk dari board elektronik Arduino.

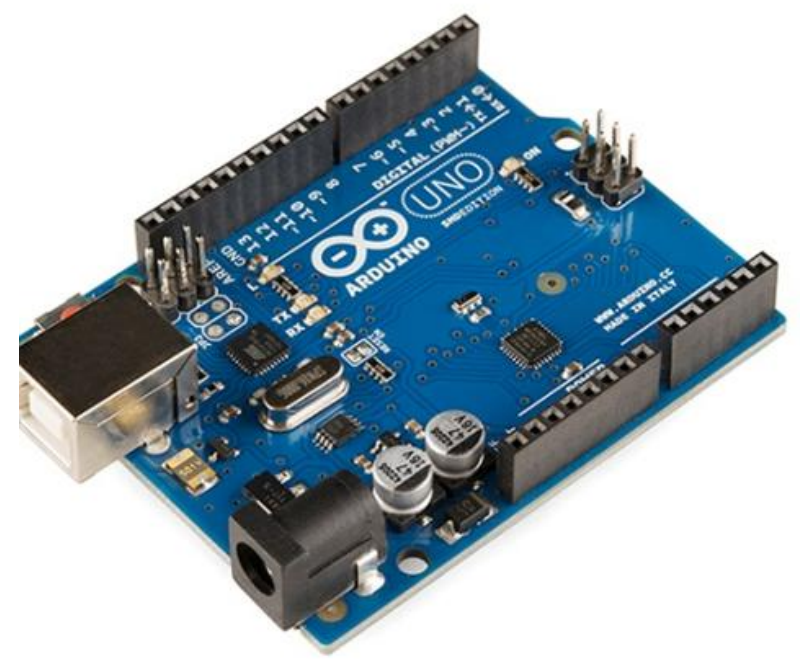

Gambar 1. Papan mikrokontroller Arduino Uno

Arduino dipilih pada penelitian ini karena Arduino merupakan platform yang dapat diintegrasikan dengan berbagai macam sensor. Sehingga diharapkan setelah penelitian ini dapat dilakukan pengembangan lebih jauh dengan menambahkan sensor-sensor untuk memonitor berbagai indicator/sinyal vital tubuh. Hal ini akan membuat proses diagnostik yang bisa dilakukan menjadi lebih variatif dan lebih akurat.

\subsection{Sensor Tekanan MPX5050DP}

Sensor MPX5050DP merupakan sebuah piezoresistif tranducer yang dirancang untuk mendeteksi adanya tekanan untuk berbagai macam keperluan aplikasi. Piezoresistif transducer merupakan transducer yang terbuat dari bahan silicon yang mampu digunakan untuk mendeteksi tekanan fluida termasuk tekanan udara dengan tingkat ketelitian yang sangat tingi. Sensor MPX5050DP ini memiliki 6 buah pin yang terdiri dari Vout, Ground, Vcc dan 3 pin lainnya digunakan untuk internal device connections. Sensor ini bekerja pada sebesar 5 volt dan mampu mendeteksi tekanan dari 0 sampai 50. Dalam aplikasinya untuk pengukuran tekanan darah, sensor ini akan mendeteksi tekanan udara di dalam manset dan kemudian dikonversikan menjadi nilai tegangan listrik, semakin besar nilai tekanan maka tegangan yang dikeluarkan akan semakin besar. Nilai tegangan tersebut $\mathrm{kPa}$ yang nantinya dapat dikonversikan menjadi tekanan darah dalam satun mmHg. 


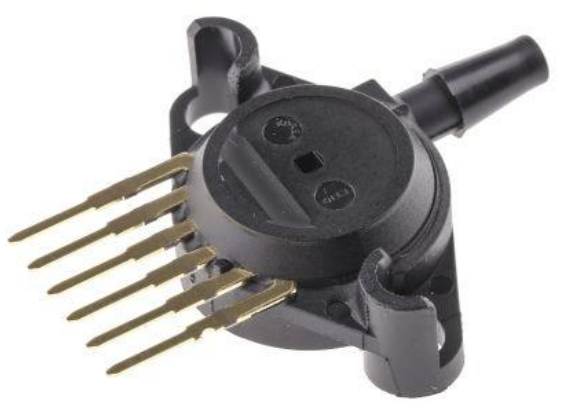

Gambar 2. Sensor tekanan MPX5050DP

\subsection{Sensor Tekanan MPX5050DP}

HC-05 merupakan modul Bluetooth SPP (Serial Port Protocol) yang mudah digunakan untuk komunikasi serial wireless (nirkabel). Perangkat ini dapat dengan mudah dipasangkan dan dikonfigurasikan dengan papan mikrokontroler Arduion Uno melalui serial port yang terdapat pada papan Arduino Uno. HC-05 memiliki dua mode kerja yakni auto-connect dan ODAP. Pada mode ODAP, pengguna dapat berkomunikasi melalui modul bluetooth ini dengan menggunakan ATcommand. Modul bluetooth HC-05 bekerja pada level tegangan 3.3V dengan kebutuhan arus $20-$ $30 \mathrm{~mA}$ saat pairing/proses koneksi dan sekitar $8 \mathrm{~mA}$ saat sudah terkoneksi. HC-05 melakukan transmisi data pada frekuensi $2.5 \mathrm{GHz}$ dengan modulasi bluetooth 2.0 dengan kecepatan maksimum 3 Mbps.

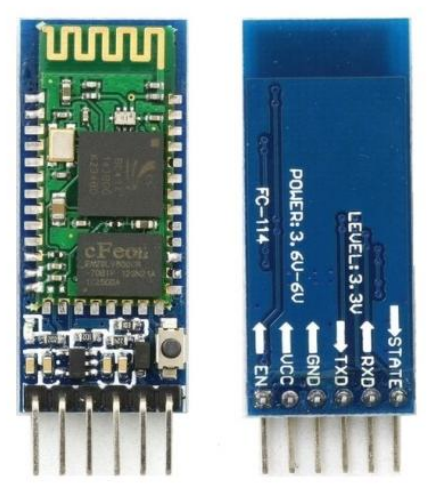

Gambar 3. Modul bluetooth HC05 untuk Arduino

\section{Metodologi Penelitian}

Penelitian ini adalah penelitian rancang bangun. Penelitian bermula dengan melakukan telaah pada permasalahn yang akan diselesaikan kemudian melakukan analisis dan pemetaan solusi dengan menggunakan sumber daya yang sesuai dan tersedia. Metode penelitian yang digunakan dalam penelitian ini mengadopsi model pengembangan waterfall dari Software Development Life Cycle (SDLC) yang sudah lazim digunakan dalam pengembangan perangkat lunak.

Meskipun produk akhir dari penelitian ini adalah perangkat keras dan perangkat lunak yang terintegrasi pendekatan SDLC tetap bisa digunakan, karena pada hakekatnya pengembangan perangkat keras dalam penelitian ini memiliki perspektif yang tidak jauh berbeda dengan pengembangan perangkat lunak. Untuk lebih jelasnya tahapan penelitian yang dilakukan diuraikan sebagaia berikut:

1. Tahapan identifikasi dan studi literature. Dalam tahapan ini peneliti akan melakukan studi literature khususnya mengenai mekanisme monitoring/pengukuran tekanan darah, mengidentifikasi beberapa alternative komponen elektronika yang bisa tersedia di pasar.

2. Tahapan desain sistem. Dalam tahapan ini peneliti akan menentukan desain arsitektur secara umum, rancangan perangkat keras serta rancangan dari mobile application. 
3. Tahapan implementasi sistem. Dalam tahapan ini peneliti akan mengimplementasikan desain program yang dibuat pada tahap kedua kedalam bahasa pemrograman dan purwarupa perangkat keras.

4. Tahapan pengujian sistem. Dalam tahapan ini peneliti akan melakukan pengujian terhadap hasil penelitian.

\subsection{Arsitektur Sikstem Umum}

Secara konseptual, gambaran alur kerja sistem yang akan dibangun diilustrasikan pada gambar 4. Sistem yang akan dikembangkan terdiri dari 2 komponen utama, yakni perangkat sensor yang digunakan oleh ibu, mobile application sebagai perangkat antar muka sistem dengan sensor, rencananya mobile application akan dipasang dengan program untuk mengimplementasikan model diagnostic berbasis data mining untuk melakukan estimasi kemungkinan terjadinya komplikasi berdasarkan data tekanan darah yang dikirmkan oleh sensor. Komunikasi antara modul sensor dengan mobile application dimediasi dengan menggunakan transmisi bluetooth. Sampai laporan kemajuan ini disusun, komponen sistem yang sudah bisa direalisasikan adalah perangkat keras untuk mengukur tekanan darah. Sedangkan mobile application masih dalam tahapan pengerjaan.

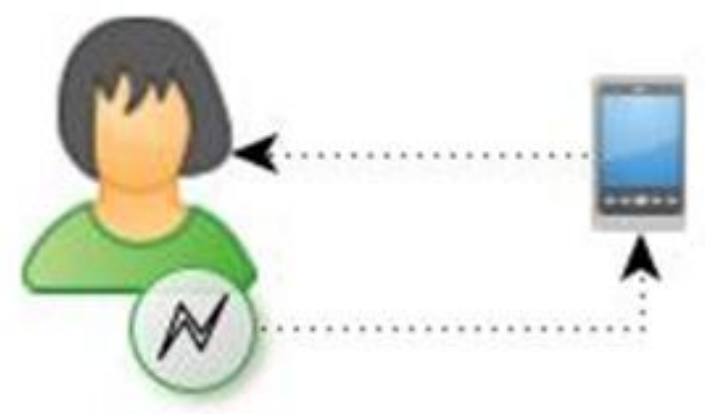

Gambar 4. Arsitektur umum dari sistem yang dikembangkan

\subsection{Rancangan dan Cara Kerja Perangkat Keras}

Gambar 5 berikut ini menunjukkan rancangan skematik perangkat keras yang dikembangkan dalam penelitian ini. Perangkat keras yang dibuat dikonfigurasikan diatas board utama Arduino Uno. Komponen-komponen lain yang digunakan antara lain sensor tekanan MPX550GP, push button, LCD 16x4, serta modul bluetooth HC05.

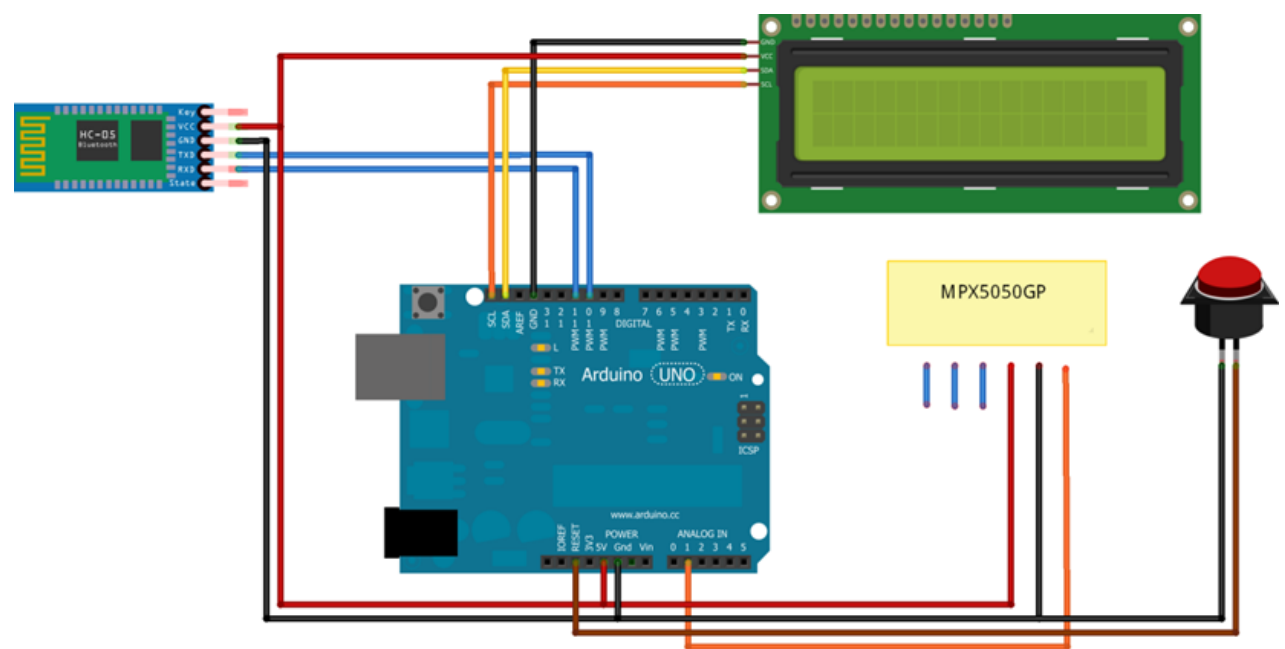

Gambar 5. Rancangan perangkat keras 
Output MPX5050DP berupa analog yang nantinya akan dikonversi menjadi nilai kilopascal $(\mathrm{kPa}) . \mathrm{kPa}$ merupakan satuan ukuran tekanan per meter persegi pada suatu bidang. Sedangkan nilai $\mathrm{kPa}$ sendiri yang merupakan satuan tekanan udara didapatkan dengan mengkonversikan nilai analog yang dikeluarkan oleh sensor dengan formulasi/rumus yang didapatkan dari datasheet[7] yang disertakan oleh manufaktur pengembang sensor MPX5050DP yakni FreeScale Semiconductor. Adapun rumus untuk mendapatkan nilai kPa diuraikan dalam formula 1 berikut ini.

$$
\mathrm{kPa}=((\text { voltage/4.5) }-0.04) / 0.018
$$

Sesuai dengan petunjuk pada datasheet koefisien 4.5 merupakan nilai maksimum dari tegangan yang dihasilkan oleh sensor MPX5050DP, sedangkan koefisien 0.04 dan 0.018 didapatkan dari hasil kalibrasi. Lebih lanjut nilai voltage didapatkan dengan menggunakan formula 2 sebagai berikut.

$$
\text { voltage }=\text { sensorValue } *(\text { voltageMax } / \text { sensorMax }) \text {. }
$$

sensorValue merupakan sebuah variable yang nilainya diperoleh dari hasil pembacaan nilai ADC oleh sensor MPX5050DP. Nilai untuk voltageMax adalah 5, sesuai dengan tegangan maksimum yang bisa diberikan oleh mikrokontroler Arduino Uno. Sedangkan nilai sensorMax adalah nilai ADC maksimum dari sensor MPX5050DP yakni 1023 bit. Setelah didapat nilai Voltage maka didapat nilai $\mathrm{kPa}$. Setelah nilai $\mathrm{kPa}$ didapatkan maka sudah bisa untuk mendapatkan nilai $\mathrm{mmHg}$ karena satuan tekanan dalam darah menggunakan satuan $\mathrm{mmHg}$. Setelah nilai $\mathrm{kPa}$ didapat maka dapat diukur satuan mmHg dengan meng kali kan nilai $\mathrm{kPa}$ dengan koefisien $7.5(1 \mathrm{mmHg}=7.5 *$ $\mathrm{kPa}$ ). Koefisien tersebut didapatkan dari datasheet sensor MPX5050DP

Jika nilai mmhg juga sudah didapatkan maka sudah bisa digunakan untuk mengukur tekanan darah. Langkah selanjutnya setelah bisa mengukur dalam satuan mmhg yaitu menentukan nilai sistolik dan diastolik. 3 hal tersebut sangat berpengaruh pada waktu dan waktu pembuangan katup udara. Penentuan nilai sistolik dan diastolic sangat dipengaruhi oleh proses penurunan tekanan pada manset yang dipasang pada lengan pasien. Proses pembuangan tekanan pada katup pembuangan membutuhkan waktu kurang lebih 25 - 30 detik untuk dapat menurunkan tekanan secara bertahap.

Secara lebih detail alurnya adalah proses pompa tekanan membutuhkan waktu sekitar 8 detik. Kemudian setelah tekanan mencapai 160mmhg maka pada proses pembuangan selama 7 detik sebelum papan mikrokontroller Arduino Uno melakukan pengolahan nilai untuk sistolik dan diastolic. Setelah proses pembuangan tekanan selesai maka Arduino Uni melakukan proses pengukuran nilai sistolik dan diastolik. Proses pengukuran nilai sistolik dan diastolic dimulai dengan melakukan pembacaan nilai Mean Arterial Value (MAP) oleh sensor MPX5050DP selama 10 - 15 detik. Tekanan sistolik dan diastolim didapatkan dengan membagi nilai MAP dalam rentang waktu tersebut dengan nilai tekanan mmHg. Nilai mmHg yang menghasilkan hasil pembagian 0.85 adalah nilai sistolik, dan yang menghasilkan hasil pembagian 0.55 menjadi nilai diastolic. Koefisien 0.85 dan 0.55 didapatkan dari hasil kalibrasi dengan melakukan benchmark pada tensimeter digital komersial standard WHO keluaran Omron[8]. 


\section{Hasil dan Pembahasan}

\subsection{Implementasi Perangkat Keras}

Bentuk fisik dari purwarupa alat yang dikembangkan dalam penelitian ini dapat dilihat pada gambar 6. Prinsip kerja alat yang dikembangkan serupa dengan tensimeter sphygnomagnometer analog yang umum digunakan. Kesamaan yang paling jelas adalah pemasangan manset pada lengan yang merupakan bagian tubuh yang memiliki denyut nadi (tekanan darah) paling besar. Selanjutnya, tensimeter digital akan mulai bekerja setelah pengguna menekan tombol (push button) start. Setelah itu, udara harus dipompakan secara perlahan kedalam manset. Sementara itu, sensor MPX5050DP akan secara kontinyu memonitor perubahan tekanan udara pada manset.

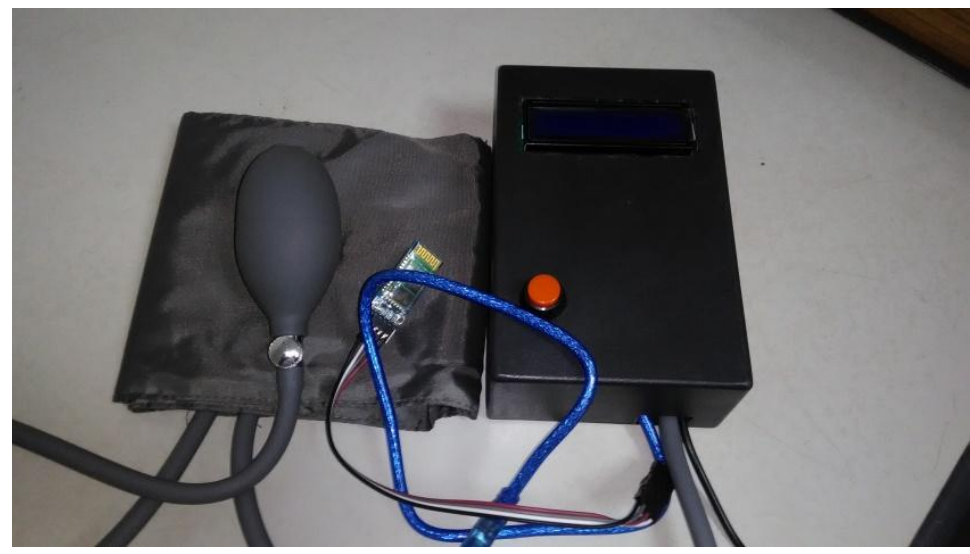

Gambar 6. Bentuk fisik alat ukur tekanan darah digital

Setelah tekanan udara mencapai $180 \mathrm{mmHg}$, tekanan udara dalam manset harus diturunkan secara bertahap dengan membuang udara secara perlahan. Pada saat tekanan udara turun bertahap, kekuatan manset dalam mencengkeram pembuluh darah juga berkurang sedikit demi sedikit. Pada saat terjadi denyut nadi untuk pertama kali, tekanan dalam manset akan berubah. Perubahan tekanan tersebut akan terdeteksi oleh sensor MPX5050DP dan dikonversikan menjadi tekanan sistolik. Tekanan diastolik akan didapatkan ketika denyut nadi yang didapatkan oleh sensor perlahan menghilang, denyut terakhir sebelum tekanan menghilang kemudian dikonversikan menjadi tekanan diastolik.

\subsection{Implementasi Aplikasi Mobile}

Aplikasi mobile yang dikembangkan dalam penelitian ini memiliki dua fungsi utama. Fungsi yang pertama adalah sebagai display tambahan untuk menampilkan hasil pengukuran disamping panel LCD yang terdapat pada alat ukur tekanan darah. Fungsi yang kedua adalah sebagai perantara/antarmuka untuk menyimpan data hasil pengukuran ke basis data. Sistem basis data yang digunakan adalah SQLite. SQLite digunakan karena sangat ringan dan data yang disimpan memiliki struktur yang sederhana. Gambar 8 menunjukkan implementasi antarmuka dari aplikasi mobile yang dikembangkan. Pada antarmuka aplikasi di menu pengukuran (gambar sebelah kiri), pengguna dapat menekan tombol "mulai" untuk melakukan pengukuran. Setelah pengguna menekan tombol tersebut, aplikasi akan secara otomatis terkoneksi (pairing) dengan perangkat ukur melalui Bluetooth. Setelah hasil pengukuran didapatkan, nilai tekanan darah sistolik dan diastolik akan dikirimkan ke aplikasi mobile. Pengguna dapat melakukan pengukuran ulang dengan menekan tombol "ulangi" atau menyimpan hasil pengukuran. Pada menu "Log Data" (gambar sebelah kanan), pengguna dapat melihat data pengukuran terdahulu, pengguna juga dapat mengekspor data kedalam bentuk CSV melalui tombol yang sudah disediakan. 

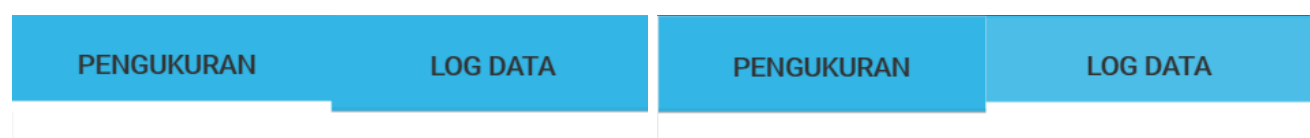

21 Agustus $2019-10: 15: 30$

Data hasil pengukuran

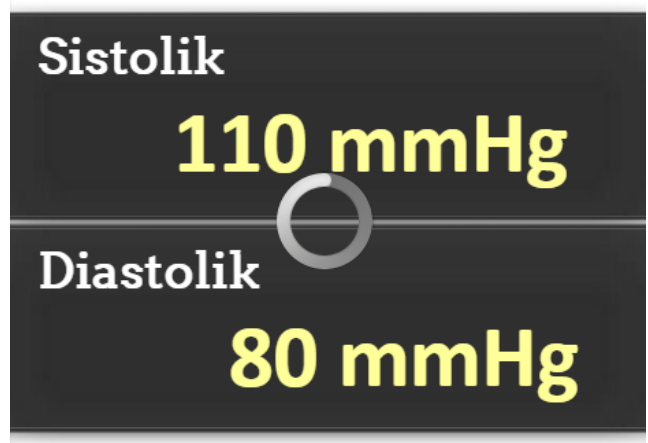

\begin{tabular}{|c|c|}
\hline 21/08/18-10:15 & $110 / 80$ \\
\hline 21/08/18-18:20 & $111 / 81$ \\
\hline 22/08/18-09:17 & $109 / 80$ \\
\hline 24/08/18-11:15 & $115 / 83$ \\
\hline 25/08/18-12:32 & $113 / 81$ \\
\hline 26/08/18-10:08 & $109 / 82$ \\
\hline
\end{tabular}
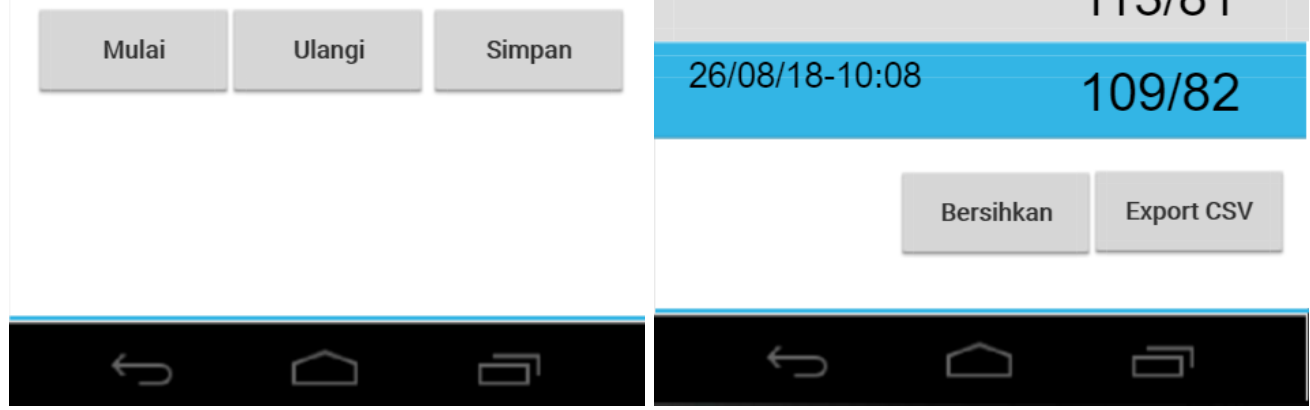

Gambar 8. Tampilan antar muka aplikasi mobile berbasis Android

\section{Kesimpulan}

Dalam penelitian ini, berhasil dikembangkan sebuah perangkat hardware-software terintegrasi untuk melakukan pengukuran tekanan darah dan penyimpanan hasil pengukuran. Beberapa hal yang dapat disimpulkan dari hasil penelitian ini adalah:

1. Dalam penelitian ini, sensor tekanan MPX5050DP berhasil dikalibrasikan untuk mengukur tekanan darah dan mengkonversikan hasil pengukurannya kedalam bentuk digital yang dapat ditampilkan pada perangkat lunak mobile berbasis Android.

2. Eksperimen yang dilakukan dalam penelitian ini berhasil mengintegrasikan perangkat keras berbasis Arduino Uno dengan perangkat lunak mobile berbasis Android dengan media bluetooth.

\section{Ucapan Terima Kasih}

Penelitian ini dilakukan dalam skema Penelitian Dosen Pemula tahun pelaksanaan 2018 yang didanai oleh Direktorat Riset dan Pengabdian Pada Masyarakat Direktorat Jendral Penguatan Riset dan Pengembangan (DRPM) Kementrian Riset dan Pendidikan Tinggi (Kemristekdikti) Republik Indonesia. Tim peneliti mengucapkan terimakasih kepada DRPM Kemristekdikti yang telah memberi kesempatan kepada tim peneliti untuk menambah wawasan dan pengetahuan melalui penelitian dalam skema ini. Semoga penelitian ini dapat membawa manfaat bagi kemajuan bangsa Indonesia. 


\section{Daftar Pustaka}

[1] Rahajeng, E., \& Tuminah, S. (2009). Prevalensi hipertensi dan determinannya di Indonesia. Majalah Kedokteran Indonesia, 59(12), 580-587.

[2] http://www.who.int/en/news-room/fact-sheets/detail/maternal-mortality

[3] Hadiyoso, S., \& Rizal, A. (2015). Instrumentasi Biomedis Berbasis PC. Gava Media. Yogyakarta.

[4] Kaur, A., Saini, S. S., Singh, L., Sharma, A., \& Sidhu, E. (2016, October). Efficient Arduino UNO driven smart highway/bridge/tunnel lighting system employing rochelle piezoelectric sensor. In Control, Computing, Communication and Materials (ICCCCM), 2016 International Conference on(pp. 1-4). IEEE.

[5] Ren, Y., \& Lyu, N. (2016, April). A pulse measurement and data management system based on Arduino platform and Android device. In Networking, Sensing, and Control (ICNSC), 2016 IEEE 13th International Conference on (pp. 1-4). IEEE.

[6] Kim, M., Kim, K., Seo, K., Lee, J., Park, K., \& Kim, K. (2017, February). Modeling process-aware Internet of Things services over an ARDUINO community computing environment. In Advanced Communication Technology (ICACT), 2017 19th International Conference on (pp. 163-166). IEEE.

[7] https://www.farnell.com/datasheets/673750.pdf

[8] http://omronhealthcare.co.id/bpm_upper-arm_hem7121.html 